\title{
Children of Library Land - the Past, Present and Future of Finnish Library Services for Children and Young People
}

\author{
Ulla Pötsönen \\ ulla.potsonen@gmail.com
}

\begin{abstract}
Finnish library services for children and young adults are an integral part of Finnish society, education and societal life. The article highlights the historical development and present day of Finnish library system as well as describes the best practices on the activities libraries provide for young clientele and their caretakers.

After World War II, Finland started a rapid rise towards being a modern nation. Reading as a pastime hobby gained popularity there were more education possibilities, the level of education was on the rise and young people spent more years in school instead of starting to work early. All this had a positive effect on library services. The changes in education and society had their effect on children's library services as well, and today children's and youth libraries are an essential part of Finnish society. Unlike in many other countries, Finland does not have school libraries in every school. At the moment, there are some excellent school libraries and dedicated school librarians but majority of schools are served with public libraries. The line between school library and public library is blurred, as majority of visits may be of pupils but the connection between high quality education and well-functioning library service has enabled libraries and schools to develop common goals, objectives and strategies.
\end{abstract}

Keywords: Finland, school libraries, public libraries, library services for children, education

\section{Development of Finland and Its Libraries}

The Republic of Finland celebrated its $100^{\text {th }}$ anniversary as an independent country two years ago. ${ }^{1}$ In spite of quite young age, the country is well developed, wealthy and modern. Just last year, Finland was announced to be the happiest country in the world by UN's Sustainable Development Solutions Network. ${ }^{2}$ The factors were GDP per capita, social support, healthy life expectancy, freedom to make life choices, freedom from corruption and generosity. ${ }^{3}$ This has happened, if not overnight but in a very fast pace. After World War II Finland was a poor, rural and a bit isolated country with no international export. So massive efforts and investments in education and welfare society enabled this rapid development. I'm happy to claim that the public library system has also done its share to make it happen.

A Nordic welfare model provides basic education free of charge for everyone. Health care, social care and child care are free/very affordable and at everyone's disposal. This also applies for

\footnotetext{
1 Ulla Pötsönen has been a children+youth librarian and booktalker, now she has transitioned into independent trainer and advocator. Her main current interests are futures foresight, sustainable development and helping libraries become more resilient. She is active in Finnish Library Association as well as IFLA ENSULIB.

Parts of this text has been presented in International Symposium on Library Services for Children and Young Adults, Gangneung Korea and published in an online newsletter of National Library of Korea, 2018.

2 The UN Sustainable Development Solutions Network (SDSN), accessed August 20 $0^{\text {th }}$ 2019, https://www.unsdsn.org/; Sustainable Development Solutions Network, World Happiness Report 2020, accessed March $3^{\text {rd }}$ 2020, https://happiness-report.s3.amazonaws. com/2020/WHR20.pdf.

${ }^{3}$ The Constitution of Finland, accessed January $12^{\text {th }}$ 2018, http://www.finlex.fi/en/laki/kaannokset/1999/en19990731_20111112.pdf.
} 
public libraries. They are considered as basic, local municipal service, which guarantees libraries' existence even when the economy is tight. In Finland there is a modern public library in every municipality. Patrons have free access to materials, equipment, services and professional staff, face-to-face as well as online. The buildings, services, book mobiles staff etc. are funded $100 \%$ with public funding (from the state and municipality).

Already at medieval times there were libraries in Finnish monasteries, but they were definitely not open for audience, children least of all. University libraries appeared in 1600s. First public libraries or reading rooms with reading circles were established in the late 1700s, as the legislation around general education and literacy spread. During 1800 s the library network expanded, so there were over 400 libraries by the end of century. These libraries already might have a shelf for children. Children's library as a concept was taken into consideration in the beginning of 1900s, the first children's department was opened in Turku city library in 1904. Story hours, guidance on holding books and other activities were held from the early 1900s.

As stated earlier, after WWII Finland started a rapid rise towards being a modern nation. Reading as a pastime hobby gained popularity, there were more education possibilities, the level of education was on the rise and young people spent more years in school instead of starting to work early. All this had a positive effect on children's library services. The changes in education and society have had their effect on the library services, and today children and youth libraries are an essential part of Finnish society. ${ }^{4}$

\section{Education System}

Finnish education system consists on early childhood education and care (at the age of 1-5 years), preschool (age 6 years), basic education (7-16 years), upper secondary education and/or vocational secondary education, higher education and after that life-long learning possibilities. Preschool and basic education are free, as well as higher education. Students at upper/vocational secondary education, universities and universities of applied sciences need to pay for their study material and equipment. During basic education also the study materials are provided to pupils. Nowadays tablets and smart devices have been replacing or enhancing study book materials already from early stage.

Teacher training is of a high level, teacher qualification being Master's degree. There are very few private schools, and the level of education is supposed to be harmonised throughout the country, whether rural or urban area. In real life this is not always the case, as the local resources vary. Also some remote parts of the country are not so desirable for teachers, so it is difficult to fill the open positions sometimes.

Teachers follow national curriculum, but there are no national exams before matriculation exam at the age of 19 nor school inspections. Local curricula is being created even on an individual school level, and it takes into consideration the demographic and regional features. The new national core curriculum (from 2016) sets high standards for increasing pupil's independent evaluation and planning skills, collaboration skills and multidisciplinary thinking. Multiliteracy, active citizenship and sustainable development are seen as core elements. As for public libraries, the curriculum places demand for high-quality services and support. ${ }^{5}$

\footnotetext{
${ }^{4}$ The development of Finnish library system, accessed May 25 th 2018, http://journals.sagepub.com/doi/pdf/10.1177/0340035212444506; Finnish Library Association, Accessed August 10 ${ }^{\text {th }}$ 2019. https://suomenkirjastoseura.fi/in-english/.

${ }^{5}$ Special Features of Finnish Education System, accessed August $10^{\text {th }}$ 2019, http://minedu.fi/en/koulutusjarjestelman-erityispiirteet; Highlights of the national core curriculum, accessed August $10^{\text {th }} 2019$, http://www.oph.fi/english/curricula_and_qualifications/basic_education/curricula_2014; Finnish Education System, accessed August 10 $0^{\text {th }}$ 2019, http://minedu.fi/en/education-system.
} 


\section{School Libraries and Public Libraries Serving Educational Institutions}

Unlike in many other countries, Finland does not have school libraries in every school. Although it has been mandatory to provide material and literacy education to all school pupils since the Grammar School Act from 1866, it can be either a school library or a public library in close vicinity/at pupils' disposal. This act has been placing more demands on public libraries and on the other hand school libraries have become obsolete in many parts of the country. Especially mobile libraries act as school libraries as their routes cover the municipality area. At the moment, there are some excellent school libraries and dedicated school librarians but majority of schools are served with public libraries. Vocational secondary schools, universities and universities of applied sciences have their own information and library services. ${ }^{6}$

How do the public libraries serve schools, teachers and young people then during the school hours and free time? That is the topic for the next chapters.

\section{Library as a Space: Designing a New Library or Renovating Present Spaces}

There is a library building in every municipality in Finland. According to National Library Service Quality Recommendation, $80 \%$ of population should have access to a library/mobile library within $2 \mathrm{~km}$. Taken into consideration the sparsely populated rural areas of Finland (only $17 \mathrm{ppl} /$ $\mathrm{km}^{2}$ ) this means a dense network of libraries and mobile library routes even at the countryside.

School children benefit from the closeness of the library or regular mobile library stop. Library services are integral part of the school day, not just a visit every now and then.

\section{Designing a New Library}

The location of libraries nowadays is a combination of accessibility and the synergy of cooperation. Most of new libraries are designed partnering a municipality centre, school, shopping mall or other public institution. The buildings may include health care center, youth house or kindergarten as well as the library. This cooperation and collaboration means better knowledge of the existing patrons and possibilities to reach as wide an audience as possible. ${ }^{7}$ Unfortunately many existing library buildings (as well as other public buildings) suffer from bad quality indoor air or even mold, so some libraries need to move premises unvoluntarily and without a great planning process.

Self-service libraries with access on a library card/personal ID guarantees better accessibility during evenings, weekends and public holidays. Libraries situated next to a school are usually open for school classes throughout the day, whether open or not. The line between school library and public library is blurred, as majority of visits may be of pupils.

\section{Renovating or Re-designing Libraries}

Tightening state budget on building new libraries forces library personnel to a great creativity when renovating and re-designing the spaces. Making the library as user-friendly as possible might include furniture on wheels providing possibilities to different layouts: performance space, workshop space, school classroom, silent reading room... Providing a steady WiFi is a basic request, also tablets or other smart devices for pupils' disposal improve the learning experience

\footnotetext{
${ }^{6}$ The state of school libraries in Finland, accessed 10 August 10 ${ }^{\text {th }}$ 2019, http://slq.nu/?article=volume-46-no-1-2013-10.

Ministry of Education, "Article about the library field in Finland", Accessed August 10 ${ }^{\text {th }}$ 2019, http://minedu.fi/documents/1410845/4150031/Library+services/65df0ce2-685f-4c3c-9686-53c108641a5c/Library+services.pdf.
} 
in the library. Library patron groups are involved with the renovating and planning project through participatory planning methods.

\section{The Importance of Library as a Space}

One cannot over-emphasize the importance of libraries as a free, third space. In addition to traditional way of looking at the library space for presenting materials and services, children and young people as well as parents, caretakers and teachers utilize the space in numerous ways: as a school class, learning space, waiting room, place for meeting and chatting, place for learning important social skills (preteen flocking, teenager hierarchies, relations with others, place to be seen...)... Not having to pay for using the space and knowing there's always an adult at the premises makes library an attractive space. Especially immigrant youth enjoy the library as a safe place, as there might not be a similar concept back in their home countries.

\section{What Happens in the Libraries: Activities, Programming}

\section{Supporting the Curriculum, Nonformal and Informal Learning}

Public libraries have a responsibility on supporting the learning and developing the multiliteracy of school children. There are several curriculum related activities and several municipalities have a written contract stating the tasks of the school and the library. ${ }^{8}$ There are also written agreements on general cultural education throughout the whole basic education. These cultural paths are structured cultural education programmes that provide regular cultural experiences for school children. One library path from my previous work place of Joensuu Regional Library consisted on 4 steps:

- $1^{\text {st }}$ graders ( 7 year old) are welcomed into the library as a group, given a library card and tour;

- $3^{\text {rd }}$ graders (10 year old) get a designated reading promotion lesson, book talk;

- $7^{\text {th }}$ graders (13 year old) participate to a media literacy workshop held together with the municipal youth work;

- $9^{\text {th }}$ graders (15 year old, last year of compulsory basic education) are given a bonus card for benefits: free renewal of a library card, free or discounted access to events if there's an entrance fee...).

Most school children visit their closest library regularly, weekly or even several times a week. During the school hours the visits are related to their school tasks, information retrieval or reading. The visits can be accompanied by the teacher or the pupils use the library independently. Most libraries provide reading diplomas, book talks, information literacy teaching (in the form of quests, quizzes...) and other activities related to school curriculum. Teachers request material according to the study topics, librarians also gather material packages for acute themes such as seasons, celebrations, theme days and campaigns. The cooperation between librarians and teachers is constant and mutual, library might send Newsletters to the schools or the institutions plan their actions for school year together.

Something extra might be the reception of reading dog in the library. Reading dogs are trained and certified animals, their goal is to strengthen the self-esteem of a child learning how to read. Kids with reading difficulties benefit from reading to dogs, as well as restless children.

\footnotetext{
8 The examples of the best practice: OECD - Innovative Learning Environment Project, Finland Active Childhood and Youth in Kuopio: Culture Path programme, accessed January $12^{\text {th }}$ 2018, http://www.oecd.org/education/ceri/49750409.pdf; Library for Citizens: The Way forward for Public Libraries 2016-2020, accessed May 25 th 2017, https://www.kirjastot.fi/sites/default/files/content/yleisten-kirjastojen-suunta-2016-2020-web-en.pdf.
} 
Some schools even have a therapy dog present in the class room helping the children to calm down and take responsibility.

An increasing part of supporting the curriculum is the usage if ICT. Coding clubs, robotics and teaching other technical novelties for school children is nowadays common in public libraries. Creating MakerSpaces for 3D printing or building robots, mathematic clubs or STEM workshops are on the border between school activities and freetime activities. One popular science workshops in many libraries has been a slime workshop. Children learn the basics of polymers and colloidic suspensions also known as slime (made from glue, potato starch, contact lense liquid, oil and liquid soap).

Naturally literature related events, such as author visits, literature workshops and theme days are celebrated together with local schools. There is a year clock of campaign days ranging from traditional celebrations to national fairy tale day, the calendar is followed both by the schools and the libraries. Theme events around popular fiction such as Harry Potter or Warrior Cats by Erin Hunter attract a varied audience.

Library is a great place for nonformal learning. Evening or afternoon workshops of creative writing, coding, science or languages provide a playful environment for meeting other children and learning new skills. Informal or accidental learning takes place in the library as well. Just taking out a book from the shelf and browsing it will teach the child something.

\section{Freetime and Family Activities}

Freetime activities are even more playful and relaxed at the library. Every summer dozens of Finnish libraries establish summer reading campaign, before Christmas there are numerous advent calendars around the literature theme. The latest hit might be creating an escape room in a literate fashion. There are countless overnight libraries or overnight libraries for plush toys taking place in libraries. The latter one is a method of presenting children different aspects of library work through pictures and videos, using their favourite toys as audience. Also it serves as a training of dealing with separation anxiety. Plush toys pictures are hugely popular, also with adults audience.

Family activities include story hours, drama or baby color baths ${ }^{\mathrm{TM}}$ are an art education method for the very smallest, combining visual, audional and tactile sensations. Events for the whole families, reading aloud campaigns and story hours improve the family bonding as well as the development of the child.

\section{Inclusive, Accessible and Divergent Activities}

Whatever the library activity might be, the accessibility issues and always taken seriously. Physical accessibility includes easy access spaces and mental accessibility. Libraries want to provide a feelingthat the library is meant for everyone and is a safe appealing space.

Children with reading difficulties or disabilites are taken into consideration both designing the library premises and acquring a varied collection. Age-approriate easy read books, e-books and Daisy material are easily recognisable and disposed. Homework help groups and study groups assist school children with difficult homework or provide a safe place to spend the afternoon, these groups are not extra (private) tutoring but more of a peer group based.

Providing access is not only about disabilities but also the variety of information for children and your people in different life situations and backgrounds. Finnish libraries do not censor material, but provide vast information about sexuality, gender, mental and other health issues and other questions concerning adolescence and growing up. Media and information literacy skills are the key to grow up as an information-savvy and citizen with civic skills required in the future.

The needs of children and families with language and cultural variety are served, whether it is about maintaining the mother tongue or integrating to Finnish society. There is a national 
Multilanguage library serving all libraries, providing material and assistance in numerous languages that a single small library cannot possibly have aquisitions. The national library of visually impaired, the national library of sign language, Sami language library and Russian language library supplement the collections. ${ }^{9}$

\section{Participatory Approach: Involving Partners and Especially Children and Young Adults to Decision-Making and Activities}

Children and young adult library services are always designed and implemented in cooperation with several actors: library community, schools, daycare, municipality youth work, culture work, social work, local associations... Schools are usually the closest partners, so there are written agreements of collaboration between libraries and schools. These agreements state and frame the responsibilities, shared actions, schedules, possible shared budgets etc. Libraries are not obliged to have these agreements by law, but they are handy for strategic planning.

But it's not only the adults who are being heard. It is stated in Finnish legislation that young people need to be aware of decisions concerning themselves and they are to be given opportunities to have an impact on the decisions. The children have right to know and affect the issues concerning themselves, already from an early age. This right has to be put into effect age-appropriately. One example of this are the Youth councils. Municipalities must facilitate a Youth council for young people aged 15-19 years. Youth councils are arenas for learning democratic policy-making and the procedures of city council meetings. Libraries often consult youth counsils for issues about teenagers, as the councils are the easiest way to reach the age group. ${ }^{10}$

For online activity, there is an online democracy tool Nuortenideat.fi. Lots of young people associations also encourage their members to active dialogue with adults on issues concerning youth.

Libraries have different types of children and young people boards or panels. They consist of active young people who want to improve their own environment and organise activities for others. The boards can be in charge of organising events or theme days, acting as a messenger between parents and library or giving direct ideas for improving the library services.

Another way of participating young people is to provide internship and summerjob possibilities in the libraries. Annually, several 13 to 15 year olds serve one to two weeks in the libraries as on-the-job-learning interns. Summer jobs are offered to young people aged 18-23 years. Students from different fields can spend 4 to 16 weeks as an intern in the libraries.

In addition to this, libraries activate children and young people with providing space for exhibitions and performances. School art project can be displayed at the local library, this way also external audience (family, relatives...) can visit the exhibition. Different types of school performances takes place in libraries regularly, whether be it music, choir, drama or dance.

Last, but definitely not least method of activating young people is regular and varied collection of feedback. National surveys and statistics combined with local surveys map the needs, wishes and grievances of the audience. Gathering the numerical information is a way of not just meeting the requirements stated by national authorities but also a tool of development. The libraries gather feedback locally from partners such as schools, parents, associations etc. on a regular basis. The opinion of young people themselves is important too. Children's librarians listen carefully their patrons, collecting feedback formally but most of the times very informally and casually. The development is based on the real needs of the community and the changes discovered in the library users (or non-users) behaviour.

\footnotetext{
${ }_{9}$ National unit of library collaboration, Libraries.fi, accessed August $10^{\text {th }}$ 2019, https://www.libraries.fi/.

${ }_{10}$ Youth Councils, accessed May $25^{\text {th }}$ 2018, http://www.nuva.fi/what-is-a-youth-council.
} 


\section{The Future of Finnish Library Services for Children and Young People}

As mentioned earlier, the development of Finnish libraries as a vital basic service has been secured by strong legislation and decision-making. The connection between high quality education and well-functioning library service has enabled libraries and schools to develop common goals, objectives and strategies. If we want to keep the status quo and even improve it, there's a lot that needs to be done.

The new national curriculum will place public libraries in front of new challenges and tasks. The changing societal environment provides challenges as well, with rapidly growing immigrant population, aging Finnish population or changing political atmosphere nationally/internationally. Following the UN sustainability developmental goals, libraries need to focus on supporting the welfare and equality.

Finnish libraries are an essential part of the network of keeping the society well educated, informed and providing possibilities of entertainment, social interaction as well as personal growth. In order to meet the challenges, library work with families, children and young people is even more relevant than earlier.

\section{References:}

1. Finnish Education System. Accessed August 10 $0^{\text {th }}$ 2019. http://minedu.fi/en/education-system.

2. Finnish Library Association. Accessed August 10 $0^{\text {th }}$ 2019. https://suomenkirjastoseura.fi/in-english/.

3. Highlights of the national core curriculum. Accessed August 10 $0^{\text {th }}$ 2019. http://www.oph.fi/english/ curricula_and_qualifications/basic_education/curricula_2014.

4. Library for Citizens: The Way forward for Public Libraries 2016-2020. Accessed May 25th 2017. https:// www.kirjastot.fi/sites/default/files/content/yleisten-kirjastojen-suunta-2016-2020-web-en.pdf.

5. Ministry of Education. "Article about the library field in Finland". Accessed August 10 $10^{\text {th }} 2019$. http:// minedu.fi/documents/1410845/4150031/Library+services/65df0ce2-685f-4c3c-9686-53c108641a5c/ Library+services.pdf.

6. National unit of library collaboration, Libraries.fi. Accessed August 10 th $^{\text {th }} 2019$. https://www.libraries. $\mathrm{fi} /$.

7. OECD - Innovative Learning Environment Project. Finland Active Childhood and Youth in Kuopio: Culture Path programme. Accessed January $12^{\text {th }}$ 2018. http://www.oecd.org/education/ceri/49750409. pdf.

8. Special Features of Finnish Education System. Accessed August $10^{\text {th }}$ 2019. http://minedu.fi/en/ koulutusjarjestelman-erityispiirteet.

9. Sustainable Development Solutions Network. World Happiness Report 2020. Accessed March $3^{\text {rd }} 2020$. https://happiness-report.s3.amazonaws.com/2020/WHR20.pdf.

10. The Constitution of Finland. Accessed January $12^{\text {th }}$ 2018. http://www.finlex.fi/en/laki/kaannokset/1999/ en19990731_20111112.pdf.

11. The development of Finnish library system. Accessed May $25^{\text {th }} 2018$. http://journals.sagepub.com/doi/ pdf/10.1177/0340035212444506.

12. The state of school libraries in Finland. Accessed August $10^{\text {th }} 2019$.http://slq. $\mathrm{nu} /$ ? article=volume-46-no-1-2013-10.

13. The UN Sustainable Development Solutions Network (SDSN). Accessed August 20 2019. https:// www.unsdsn.org/.

14. Youth Councils. Accessed May 25 ${ }^{\text {th }}$ 2018.http://www.nuva.fi/what-is-a-youth-council. 


\section{Деца у земљи библиотека - прошлост, садашњост и будућност финских библиотечких услуга за децу и младе}

\section{Резиме}

Библиотечке услуге за децу и младе представљају саставни део друштвеног живота и образовања у Финској Текст приказује историјски развој и садашњост финског библиотечког система и описује примере најбоље праксе у домену активности које библиотеке обезбеђуіу за младе и њихове старатеље.

Након Другог светског рата, финска нација је започела убрзано да се креће у правцу модернизације. Читање из разоноде и задовољства постало је популарно, било је више могућности за образовање, образовни ниво је растао, а млади су проводили више година у школи, уместо да рано почну да раде. Ови трендови допринели су да се развију разноврсније библиотечке услуге. Промене у образовању и у друштву утицале су и на библиотечке услуге за децу те тако данас библиотеке за децу и младе представљају есенцијални део финског друштва. За разлику од многих других земаља, у Финској не постоји школска библиотека у свакој школи. Тренутно делују неколико изврсних школских библиотека и посвећених школских библиотекара, али већина школа користи услуге јавних библиотека. Линија измећу школске и јавне библиотеке није јасно повучена јер највећи број посета остварују можда управо ученици, али веза измећу висококвалитетног образовања и ефикасне библиотечке услуге омогућује библиотекама и школама да имају заједничку сврху, циљеве и стратегију.

Кључне речи: Финска, школске библиотеке, јавне библиотеке, библиотечке услуге за децу, образовање 


\section{(C) $(\mathcal{Q} \Theta \Theta$}

Деца у земљи библиотека - прошлост, садашњост и будућност финских библиотечких услуга за децу и младе by Ulla Pötsönen is licensed under a Creative Commons Attribution-NonCommercial-NoDerivatives 4.0 International License. 